\title{
The Effect of Liquidity and Capital Structure on Organization Performance: Evidence from Banking Sector
}

\author{
YASIR KHAN \\ Ph.D Scholar, Qurtuba University Peshawar \\ yasirok62@yahoo.com \\ DR. SAIMA BATOOL \\ Assistant Professor, Qurtuba University Peshawar \\ dr.saimabatool90@yahoo.com \\ DR. MUHAMMAD ASAD KHAN \\ NUML Peshawar Campus \\ masad@numl.edu.pk \\ MUHAMMAD IDRIS \\ Assistant Professor, Department of Education \\ Abdul Wali Khan University, Mardan \\ midrees@awkum.edu.pk
}

\begin{abstract}
This study title as Effect of liquidity and capital structure on Financial Performance: Evidence from Banking Sector. This study investigates Effect of liquidity and capital structure on Financial Performance in banking sector. The study was conducted using 10 banks as a sample out of 64 banks in the Pakistan. The results were obtained using correlation and step wise regression to know the direction, association and impact of variables and the effects of liquidity and capital structure on performance. The result found that liquidity and capital structure affects the performance positively in banking sector. Therefore it is suggested that banks should exercise such practice. All the hypotheses developed for this study has been achieved through the analysis of this research study.
\end{abstract}

Key words: Liquidity, Capital Structure, Organization Performance, Schedule Banks in Pakistan.

\section{Introduction}

Liquidity is a measure of the extent to which a person or organization has cash to meet immediate and short term obligation, or asset that can be quickly converted to do this. Whereas, capital structure is indicator of how profitable a company is relative to its total assets. Return on investment gives an idea as to how efficient management is at using its assets to generate earnings. Calculated by dividing a company's annual earnings by its total assets, Return on assets is displayed as a percentage. Sometimes this is referred to as "return on investment". The capital of the firm is as "those pool of funds 
that the company commits to its fixed assets, to inventories, to account receivables, and

to cash or marketable securities" which lead to corporate growth. capital are important in any business development for well capital structured a business firm must select best plan for various ways of selecting the best components of the capital and that is used in the operation of a company to raise its productivity and to achieve performance. The whole process should be based on criteria which are well drawn by the finance manager after the financial planning for the company (Uremadu, 2004). An economist considers capital as any material that is consumed for the production to make wealth. Hence capital can be said as factors of production the factor of production are basically divided in money, man, and machinery and the forth one is information (Efobi, 2009). The ability of a firm to choose sources of capital for its operations is a difference between a good managed capital structure and a poorly managed capital structure. Liquidity is important for company existence. This has effect on financial costs changes, changes in the sales dynamic and it influence on risk level of that company. According to Kesimli \& Gunay (2011), liquidity is refer to the relation of investment in current Assets and current liabilities that are converted within the year as well as paid within the year concern so that very imported as concerned with daily operation.

The relation of working capital and Liquidity is very close, the generation of revenue is depended on working capital and working capital is relatively connected with liquidity. They further added working capital management importance that working capital management is extremely very important and today the success and failure of any firm can be determined through it. They further added that working capital management directly effect on firm's profitability. Filbeck\& Krueger (2005), argued that by managing the component of the working capital business can get high rate of success. Some of the researchers like Almajali et al, (2012), Liargovas\& Skandalis, (2008), also support the same positive effect of the working capital management on the financial performance of the firms, they added that some of firms may implement aggressive policy while other use conservative working capital management policy to achieve the firms overall goals. In developing countries much of the studies have been so far conducted to analyzed the result of working capital management on financial performance of the firms, In Kenya a number of studies have been done on this issue in non financial listed companies at the Nairobi Securities Exchange as a result to get how liquidity affects the financial performance. Effect of liquidity on management of an organization is very attractive and exciting although very subtle in measurement of financial performance.

\subsection{Problem Statement}

Liquidity and capital structure refers to the ability of the business to meet its cash obligations within a specific time period. Capital structure, profitability and liquidity are related concepts, but by no means are they equivalent. Unlike profit, cash flow includes loan principal payments, proceeds from liquidated assets and family living expenses. Cash flow does not include profitability factors such as depreciation, the value of inventory changes, or capital gains and losses. Liquidity is best measured with cash flow statements or budgets. When firms have problems with liquidity they may defer their payments to creditors which is a harmful for companies and can result in several 
consequences such as worse credit terms in the future. This in the long run adversely affects profitability. According to the KSE (2010), a number of public and private companies have been under statutory management in the last decade due to liquidity issues.

\subsection{Objectives of the Study}

- To analyze and describe the pattern of liquidity and capital structure practices in banking sector for the period of 2005-2014

- To investigate the effect of capital structure and liquidity on financial performance of the firm.

- To suggest measures to improve the mechanism and framework for liquidity and capital structure in banking sector.

\section{Literature Review}

Capital structure means that firm finances their assets through combination of equity, debt and hybrid securities. Let's imagine a perfect capital market where there is no transaction or bankruptcy costs and perfect system of information and importantly firms and individuals can borrow at the same interest rate with no taxes due to which investment decisions are not affected by financing decisions. Two findings Modigliani and Miller found in the stated circumstances. The value of the firm is in depended to capital structure this is the first preposition. The leveraged firm and the cost of equity is equal as it's for the cost of equity for an unleveraged firm and with it premium of risk is also associated. Which is like if the leverage increases, so then the burden of individual risks is shifted in different classes of investor so total risk is conserved and no extra value created? Capital structure is also defined as the various option of financing of the asset with a firm. Rahemen, Zulfiquar and Mustafa (2007) argued that a concern with business go to the multiple mixture of debt and equity which have emphasis on maximizing the market value of a firm because Capital structure directly relation with the liquidity and profitability of a firm.

The conclusive significance of liquidity means that for company development it is very important and at the same time it is one of the important factors which responsible for company market position. Liquidity is vital for a firm existence. It mostly has an effect on financial costs reduction or growth. The consequence of liquidity to a firm performance guided to a conclusion that it settle profit level of firm. The essential issue to financial manager is to find out the suitable mix between equity and debt to a firm. The mix of debt and equity called as firm's capital structure. A financial manager struggles to attain best capital structure for firms which increase the market value of the firm and also assure satisfactory liquidity (Uremadu, 2009).

Capital adequacy refers to the sufficient amount of banks equity to absorb any shock that a bank may experience (Ong \& Teh, 2013). The use of debt has impact on firm's The total capital of a company or a firm is "a stock of money, possessed by a person or a business firm, that could be invested, from time to time, in order to earn income, but for which it is intended not to diminish". Akinsulire (2002) an economist considers capital as any material that is consumed for the production to make wealth. They are said as factors of production which are divided into man, machine and money and information the fourth division (Efobi, 2009). Efobi (2009) also added about the 
capital structure and the liquidity of the firms after analyzing the Ghana Stock exchange during 2000 to 2010 and found that they are highly geared. This effect is because of the attributed to their over dependency on short term debt as a result relatively high Bank of Ghana Lending rate and low level of bond market activities and there is a negative relationship between gearing and the banks performance (Awunyo \& Badi, 2012).

According to (Uremadu 2004) that the capital is the pool of fund or it is a bunk availability to purchase an asset or group of assets for running of a business routine work as well as the overall business. An indicator of how profitable a company is relative to its total assets. ROA gives an idea as to how efficient management is at using its assets to generate earnings. Calculated by dividing a company's annual earnings by its total assets, ROA is displayed as a percentage. Sometimes this is referred to as "return on investment" (Uremadu, 2004). Clarke (2004) argued about the capital structure and liquidity in his study "cycle of crises and regulations" that the inefficient working capital structure lead to failure and crises for an organization which definitely highly impact on the return i-e return on assets and return on equity. The capital structure need keen attention of the policy maker due attention should be given at the time of making any strategies. The mangers of an organization are the agent of the shareholder in an organization and they are working on behalf of the share holders they are trying to increase the wealth of the share holders. Mangers are the experience people and having the relevant skill and knowledge to handle each and every critical situation. A corporation with liquid stocks can increase its stock price (Diamond and Verrecchia, 1981; Holmström and Tirole, 1993), offer more motivations for insiders to create worth (Faure-Grimaud and Gromb, 2004), and boost shareholder interference (Kyle and Vila; 1991; Kahn and Winton, 1998; Maug, 1998; Noe, 2002). Maug (1998) offer a theoretical framework to display that liquid stock markets to control the difficulties, support active corporate governance. Fang, Noe, and Tice (2009) offer empirical proof that liquidity is increase the stock value because liquidity encourages trades by up-to-date investors and results in more explanatory stock prices and improved managerial motivations. However, Fang, et al. (2009) do not find solid proof to support that liquidity develops active governance and monitoring. The realistic relation between a corporation's stock liquidity and performance, mostly the corporate governance effects of stock liquidity.

Claessens (2002) described that liquidity play very vital role in the firm significances toward profitability and potential to meet their operational expenditure. Every organization strives to keep the profitable track for their organization. Profitable transaction need to keep liquid amount that is cash for making their operational payments and to avail the benefits of cost reduction. It also increase stakeholder trust as well as increase value of share holder wealth. The corporation is failed in stock liquidity due to the absence of solid proof on the corporate governance effects: (i) the significance of corporation and industry is determined corporate governance arrangements and shareholder worth (Johnson, Moorman \& Sorescu, 2009; Larcker, Ormazabal \& Taylor, 2011); (ii) Monitoring the industry Backgrounds which show the relation among stock liquidity and governance (Brockman and Chung, 2003; Chung, 2006); and (iii) stock liquidity can be improved by corporate governess (Holmström \& Tirole, 1993; Maug, 1998). 


\subsection{Theoretical Review}

2.1.1 Liquidity Management Theory

\subsubsection{Commercial Loan Theory}

Adam Smith developed this theory in England during the 18th century. According to Adam smith, a profitable bank must offer small period liquidating advances to meet working capital desires. The bank should stop long period's advances. Profitable bank deposits are basically advances and should have short term self-liquidating liabilities. The bank should follow a principle which is called Real Bill Doctrine, according to Real bill doctrine as and when bank lent money on self-liquidating papers the new loan should not be granted until the previous loan repaid. The doctrine criticized on some of reason that in Economic depression goods cannot be moved easily into a normal channel of trade so the prices fall and falling in price it become losses to sellers. The genuine transaction for which the loan granted the debtor will not be able to repay the loan. The next criticism was that the bank can only ensure their liquidity of its assets when it readily convertible into cash without loss. That's why the commercial loan theory was failed to become in practice.

\subsubsection{Shiftable Theory}

The pioneer of this theory was Moulton establish the theory in USA in 1918, in the stable theory it is indicated that the issue of liquidity is not an issue but moving of assets with no material misfortune. Moulton indicated "to attain minimum reserves, relying on maturing bills is not needed but maintaining quantity of assets which can be shifted to other banks whenever necessary. It must fulfill the attributes of immediate transferability to others without loss. In case of general liquidity crisis, bank should maintain liquidity by possessing assets which can be shifted to the Central Bank".

\subsubsection{Liability Management Theory}

Anglo-Saxon during 1970s indicated the liability management theory that financial institutions interest rates turned out to be progressively unpredictable. This is one of the imperative liquidity management theories. The liability management theory holds that banks can meet their liquidity prerequisites by offering in the business sector for extra supports to take care of advance demand and deposit withdrawal. There is no compulsion to follow old liquidity norm like keeping up fluid resources or fluid speculations. As indicated by the liability management theory, an individual bank may require reserve from diverse sources by making extra liabilities against it. These sources contain various things like issuance of time certificate of deposit, acquiring credit from other commercial banks; borrowings from the Central Bank, issuing so as to raise capital fund offers shares and by method of retain earning.

\subsubsection{Financial Performance Determinants}

There are many factors as internal and external which affect the performance of firms (Al-Tamimi, 2010; Aburime, 2005). Many factor influence financial performance of a company. Some of them are specifically connected with firm while other are connected to market. Though, the senior managers are responsible to evaluate the risks 
and take appropriate actions for securing the company's financial position. The required cash availability to trade with supplies and customer must be ensured. The some of the factors which effects on the financial performance of the banking firms are Liquidity, inflation rates, corporate governance practices, distribution networks, growth of informal sector, management information systems and product diversity among others.

\subsubsection{Liquidity}

The ratio analysis are used to indomitable the Liquidity position of a firm. Current ratio, quick ratio and operating cash flow ratio (Operating Cash Flow Ratio $=$ Operating Cash Flow / Current Liabilities) are used to assess the liquidity measurement. Gosh (2009) stated that concern on ration analysis are being important for firms as they need to sell inventory, they also need a customer to buy that inventory. For measuring the company's liquidity operating cash flow ratio are used. The result if become less than 1 will definitely indicate that the company for payment of short term liabilities has not much enough cash which may signal the managers to give attention on acquiring the capital. That's why many investors and analysts prefer higher operating cash flow ratios. For time being in the case of company is in the positing for launching the second manufacturing plant at that time the low operating cash flow ratios is not bad thing.

\subsubsection{Inflation Rates}

There is presently a generous group of confirmation demonstrating that high rates of inflation can have adverse effects on the financial performance of an organization. A growing theoretical literature describes mechanisms depicts components whereby even unsurprising increments in the rate of inflation effects on the performance at all. Particularly, recent theory underline the significance of informative asymmetries in credit market and show how increments in the rate of inflation unfavorably influence credit market grindings for negative repercussions for financial sector specially banks (Huybens $\&$ Smith 1998, 1999). Because of inflation the cost of products increases and hence the net revenues decrease, decreasing the financial performance of the organization.

\subsubsection{Corporate Governance Practices}

Corporate governance alludes to the way in which an organization is coordinated, managed, and controlled. Corporate governance also concerns the connections among the different internal and outside stack holders included and in addition the governance procedures intended to help a company accomplish its objectives. Prime significance is those systems and controls that are intended to eliminate agency problem the problem of agent "Manager" and principle "shareholder" (Kent \& Ronald, 2010). Corporate governance guarantees transparency and credibility which improves firm performance. The stakeholders are benefited through corporate governance practices. It helps how to govern the organization to achieve the assign goal. Corporate governance helps through tools and concepts that eliminates agency problem- the problem between principle (share holders) and agent (Manager) by H. Kent Baker and Ronald Anderson (2010). La Portaet al (2000) argues that Corporate governance is a technological system which provide a safe guard to the external stockholder from the internal stakeholder, we can say that it is a methodology and practices through which both the internal as well as external stockholders stake are safe and protected from each other exploitation.

\subsubsection{Distribution Networks}


According to Barthélemy (2008) argues that system's effect resources and governance structure on the financial performance of the chain, he utilizes as performance criteria a mix of return on sales (ROS) and return on assets (ROA). The analyses of Perdreau et al. (2010) stated that the financial performance (ROA) coming about because of plural structures in franchising chains. Considering the mean turnover for every system, Chaudey and Fadairo (2010) highlight the positive impact of all the more obliging contracts for the retailers. Madanoglu et al. (2011) investigate whether franchising units accomplish a superior financial performance than non-franchising ones. Sharp distribution channel helps in expanding client base and henceforth high turnover volumes, prompting better performance for the firm.

\subsubsection{Growth of Informal Sector}

As per the International Labor Organization, the informal division basically covers the disorderly range of monetary activity in trade, agriculture, development, assembling, transportation and services. It ingests maximum percentage of the work power in urban territories of developing nations. This essentially incorporates the bit of a nation's economy that lies outside of any formal regulatory environment. No strong approach found about how firms consider the decision to formalize their status and whether they are acting in a rational way to maintaining a strategic approach from the cost of having a place with the formal part. De Mel and McKenzie (2013) intended to reveal insight into this inquiry, especially from the firm profitability point of view.

\subsubsection{Product Diversity}

Rumelt's (1974) spearheading study indicates that the relationship between corporate diversification and firm performance has pulled in more consideration than some other area of strategic management research. The past research has given more attention on associating profitability differentials with distinctive diversification strategies. Rumelt (1974) set the pattern for developing so as to result examination scientific categorization of enhancement methods. He found that related diversification was connected with a higher profitability than was unrelated diversification and that then the narrow focused related constrain was more productive than the looser relatedconnected diversification.

\subsubsection{Empirical Review}

This research is conducted to investigate the effect of liquidity and capital structure on financial performance: evidence from banking Sector. The dependent variable is the financial performance as measured by Return on Assets (ROA) and Return on Equity (ROE). Liquidity as measured by current proportion and working income proportion (Operating Cash Flow Ratio= Operating Cash Flow/Current Liabilities) are the two principle free variables of the study.

\subsubsection{International Evidence}

A study by Cho and Kim (2007) reasoned that firm's profitability and liquidity are influenced by working capital management. The study utilized pooled information for the period somewhere around 2006 and 2008 to survey the organizations recorded in the Vietnam Stock Exchange. The study concentrated on cash conversion cycle and related components to quantify working capital management. The study found that the connections among these variables were emphatically negative, recommending that 
benefit is contrarily affected by an increment in real cash conversion cycle. The study also found that profitability increments as the debtor collection period and stock conversion period decrease. The present study operationalized working capital management as aggressiveness and conservatism as measured by the extent of current liabilities to total assets and total liabilities.

In a study directed to focus the impact of working capital management on profitability of Indian firms, Sharma and Kumar (2011) utilized a specimen of 263 nonmonetary firms recorded on the Bombay Stock Exchange amid 2002 to 2008. Information was examined utilizing OLS multiple regression. They found a positive relationship in between working capital management and firm profitability, despite the fact that the relationship between cash conversion cycle and return on assets was not statistically significant. The study also found that account receivables are positively correlated to return on assets and that the account payables are negatively related to return on assets.

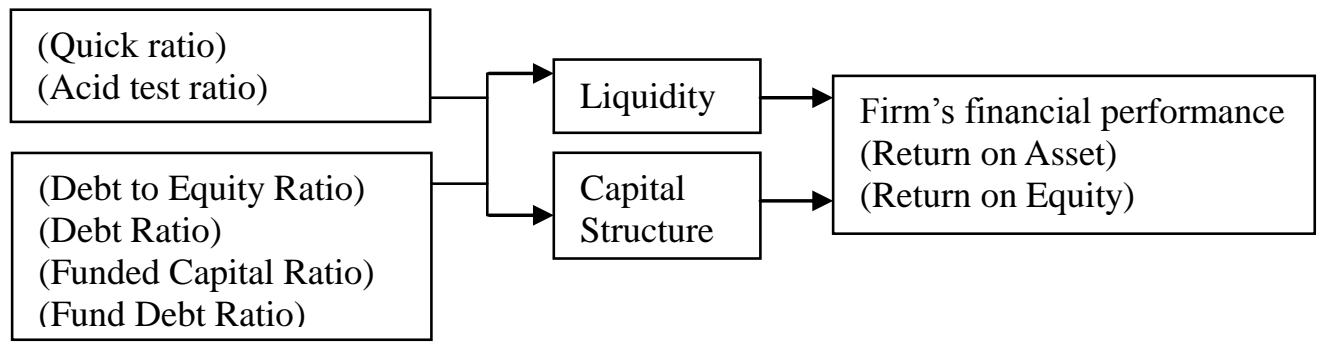

\subsection{Hypotheses}

Figure 1: Theoretical Frame Work

$\boldsymbol{H}_{1}$ : $\quad$ Firm liquidity has a significant effect on the financial performance of banks.

$\mathrm{H}_{2}: \quad$ Firm capital structure has significant effect on corporate return.

\section{Research Methodology}

This describes the research methodology that was used to study the effect of liquidity and capital structure on the performance. It also gives the population size, data collection techniques and how the data was analyzed. It also talks about the data analytical models and test of significance used in arriving at the conclusions.

\subsection{Type of Research}

Descriptive Research and co relational research utilizing combination of quantitative and quantitative research approaches.

\subsection{Data Collection}

Secondary data for this research has been used which includes annual reports of selected banks, data banks of state bank of Pakistan. Data collect from annual report of the selected banks, SECP and balance sheet analysis of Joint Stock Corporation by state bank of Pakistan. The selected data comprise on Ten year started from 2005 to 2014.

\subsection{Sample Plan}

As sample represent the small but proportionate representation portion of the population being considered for the research analysis or the number of observation being taken to conduct analysis. Random sampling technique has been used to conduct this 
research study. The sample size of this research is the ten banks out of the total Sixty seven banks in the banking sector selected through random sampling technique.
i) Khushali Bank
ii) Allied Bank
iii) Summit Bank
iv) National Bank of Pakistan
v) Habib bank
vi) Mezan Bank
vii) Bank Alfalah
viii) Standard Chartered Bank
ix) United Bank
x) Muslim Commercial bank

\subsection{Data Analysis}

The data analysis has been calculated by using correlation and ratio analysis test.

\subsubsection{Research Models}

$\mathrm{ROA}=\mathrm{B}_{0}+\mathrm{B}_{1} \mathrm{D}_{1} \mathrm{E}+\mathrm{B}_{2} \mathrm{DR}+\mathrm{B}_{3} \mathrm{FCR}+\mathrm{B}_{4} \mathrm{FDR}+\mathrm{B}_{5} \mathrm{QR}+\mathrm{B}_{6} \mathrm{CR}+\mu$

$\mathrm{ROE}=\mathrm{B}_{0}+\mathrm{B}_{1} \mathrm{D}_{1} \mathrm{E}+\mathrm{B}_{2} \mathrm{DR}+\mathrm{B}_{3} \mathrm{FCR}+\mathrm{B}_{4} \mathrm{FDR}+\mathrm{B}_{5} \mathrm{QR}+\mathrm{B}_{6} \mathrm{CR}+\mu$

Where

ROA stands for return on Assets, proxy for bank profitability,

ROE stands for return on Equity

D/E for Debts to equity ratio,

DR for debt ratio variables,

FCR for Funded capital ratio

FDR for Funded debt ration

QR for Quick ratio,

$\mathrm{CR}$ for current ratio and

$\mu \quad$ is the error term.

\section{Data Analysis}

\begin{tabular}{|c|c|c|c|c|c|c|c|c|}
\hline & ROA & ROE & $\mathbf{D} / \mathbf{E}$ & DR & FCR & FDR & QR & CR \\
\hline ROA & 1.000 & & & & & & & \\
\hline ROE & 0.341 & 1.000 & & & & & & \\
\hline$D / E$ & -0.121 & -0.142 & 1.000 & & & & & \\
\hline DR & -0.223 & -0.261 & 0.215 & 1.000 & & & & \\
\hline FCR & -0.181 & -0.152 & 0.217 & 0.078 & 1.000 & & & \\
\hline FDR & -0.213 & -0.245 & 0.219 & 0.121 & 0.131 & 1.000 & & \\
\hline
\end{tabular}




\begin{tabular}{|lllllllll|}
\hline QR & 0.252 & 0.312 & 0.071 & 0.215 & 0.281 & 0.211 & 1.000 & \\
CR & 0.312 & 0.281 & 0.091 & 0.181 & 0.334 & 0.222 & 0.351 & \begin{tabular}{l}
1.0 \\
\hline
\end{tabular} \\
\hline
\end{tabular}

\section{Table 4.1: Correlation}

The above table 4.1 shows the correlation matrix of all independent and dependent variables. The results of the above correlation table shows that liquidity is positively correlated with financial performance as quick ratio and current ratio shows positive correlation with all financial proxies like return on assets, return . The level is significant of liquidity with

\begin{tabular}{|cclll|}
\hline Variables & Coeffient & $\begin{array}{l}\text { tander } \\
\text { error }\end{array}$ & $\mathbf{t}$ & P. value \\
\hline D/E & 0.0245 & 0.0204 & -1.2 & 0.067 \\
DR & 0.1366 & 0.0607 & -2.25 & 0.001 \\
FCR & 0.4281 & 0.2378 & -1.8 & 0.061 \\
FDR & 0.0856 & 0.0387 & -2.21 & 0.001 \\
QR & 0.0899 & & 2.52 & 0.001 \\
\hline
\end{tabular}

variable financial

performance proxies. The capital structure variables i.e. debt to equity, debt ratio, funded capital ratio and funded debt ratio shows negative correlation with financial performance of banks performance.

\section{Table 4.2: Regression Analysis- MODEL 1}




\begin{tabular}{|lllll|}
\hline & & .0357 & & \\
$\mathrm{CR}$ & 0.0258 & & & \\
& & 0083 & 3.12 & 0 \\
\hline
\end{tabular}

$\mathrm{ROA}=\mathrm{B}_{0}+\mathrm{B}_{1} \mathrm{D} / \mathrm{E}+\mathrm{B}_{2} \mathrm{DR}+\mathrm{B}_{3} \mathrm{FCR}+\mathrm{B}_{4} \mathrm{FDR}+\mathrm{B}_{5} \mathrm{QR}+\mathrm{B}_{6} \mathrm{CR}+\mu$

R.square.0.56, adjusted R.square.0.55

F. Value $=16.55$

The results of the above model 1 suggest that debt to equity ratio has negative significant impact on the financial performance of banks. Debt ratio has negative significant impact whereas funded capital ratio and funded debt ratio has negative insignificant and negative significant impact respectively. Suggesting that an increase in capital structure proxies will definitely affects negatively the profitability of banks in Pakistan. The R.square0.56 suggests that almost 56\% changes in dependent variable return on equity are caused by the set of independent variable. Both proxies of liquidity quick ratio and current ratio show positive significant relationship with the financial performance of banks.

F. Value $=16.55$ means that over all model is significant. 
Table 4.3: MODEL 2

\begin{tabular}{|l|l|l|l|l|}
\hline Variables & Co-efficient & standard error & T. value & P. value \\
\hline D/E & 0.0255 & -0.0181 & -1.41 & 0.061 \\
\hline DR & 0.1351 & -0.0518 & -2.61 & 0.001 \\
\hline FCR & 0.4001 & -0.2632 & -1.52 & 0.071 \\
\hline FDR & 0.0561 & -0.0229 & -2.45 & 0.001 \\
\hline QR & 0.0511 & 0.0164 & 3.12 & 0 \\
\hline CR & 0.0411 & 0.0146 & 2.81 & 0.001 \\
\hline
\end{tabular}

$\mathrm{ROE}=\mathrm{B}_{0}+\mathrm{B}_{1} \mathrm{D}_{1} \mathrm{E}+\mathrm{B}_{2} \mathrm{DR}+\mathrm{B}_{3} \mathrm{FCR}+\mathrm{B}_{4} \mathrm{FDR}+\mathrm{B}_{5} \mathrm{QR}+\mathrm{B}_{6} \mathrm{CR}+\mu$

R. Square $=0.48, \mathrm{~F}$. Value $=12.56$

The table shows that debt to equity has negative insignificant impact on the financial performance of banks: both debt ratio and funded debt ratio has negative significant impact whereas funded capital ratio showing insignificant impact on the financial performance of banks. The liquidity process i.e. quick ratio and current ratio shows positive significant impact on the financial performance of banks R. square 0.48 suggest that almost $48 \% \Delta$ has been bought by the set of independent variable s of this study. $\mathrm{F}$. values are showing significant live i.e. more than 4 mean that over all model is significant.

\section{Findings}

- The result of this study find that debt to equity is negative correlated with financial performance proxies

- The result also finds that debt ratio is significantly negative correlated with the financial performance proxies of banks in Pakistan.

- The result find that both funded capital ratio and funded debt ratio are negative correlated with financial performance of banks in Pakistan.

- The study result find that both proxies of liquidity i.e. quick ratio and current ratio showing positive correlated with the banks financial performance.

- The results R.squres of different models find that all independent variables putting impact on dependent variable (financial performance)

- The result of this study find that all four models of this study are significant

- The result finds that capital structure variable i.e. debt to equity and funded capital ratio has insignificant impact on the financial performance.

- The result find that debt ratio and funded debt ratio proxies of capital structure has negative significant impact on the financial performance of banks in Pakistan

- The result of this study finds that both quick ratio and current ratio have positive significant impact on the financial performance.

\subsection{Conclusion and Recommendations}

This study was conducted, knowing the impact of liquidity and capital structure on the financial performance of banks in Pakistan for the period of 2005 -2014. The 
variables used in this study were firm capital structure and liquidity as independent variable and financial performance of banks as dependent variable. The result found that both capital structure and liquidity is very vital for the performance of banking sector in Pakistan. The result revealed that capital structure proxies have very negative impact on the financial performance of banks and liquidity also should positive significant impact on the financial performance of banks. The result find that capital structure proxies negative correlated with financial performance and liquidity positive correlated with banks performance. The basis of results it is suggested that banks should best combination debts and equity to maximizing the restructure and it should also look at cash and cash equivalent resources, so as to maximizing returns and build trust and confidence of the investors and depositors.

The past study about the corporate governance indicates that many a large numbers of corporations become bankrupt, because of mismanagement of capital structure. Some of researchers find that corporate failure or success depends on its working capital management. The managers are mostly responsible for its destiny. Each and every individual as well as institution want save investment and return therefore every one trying to invest in profitable and sound firm. The discussion leads to many arguments. The basic and important questions are as follows:-

1. First question which arises is that liquidity really matters in today's corporate world?

2. What is the effect and implications of capital structure on corporate governance and also on firm performance?

Its known certainties that in today's firms which are possessed by private investor are profiting and are much more productive then firms operated by the public agencies. That is private firms are more beneficial then public organizations. The above studies also support the same statements that the private firms are more benefited comparing to public own agencies being having efficient working capital management.

\subsection{Suggestions}

- As capital structure variable i.e. Debt to Equity, Debt ratio, funded credit ration, and Funded debt ratio showing negative correlation with FP. it is suggested that banks should reduce the level of these radios. Specifically Debt ratio and Funded credit ration has significant negative impact which need to decrease or the banks work and to get on optimal level of capital structure which will not affect its Financial performance. So, the banks in Pakistan should focus on its capital structure as it is vital for banks profitability. The best and optimal level of capital structure will definitely has positive impact on the financial performance banks in Pakistan. The decision makers of these banks should focus on while making capital structure i.e. debts and equity combination as. It is very significant for smooth and profitable operation of banks.

- Liquidity is very vital for the profitable operation and improved financial performance of banks. It both proxies used in this study i.e. QR and CR should positive significant impact on the financial performance of banks. On the bases of the result it is suggested that commercial banks should more focus on its cash and equivalent resources as it has positive impact on the financial performance and turn 
a motivator for the investor move towards banks and develop trust of investors and stakeholder towards banks and encourage deposit holders.

\section{Reference}

Agrawal, A., \& Knoeber, C. R. (1996). Firm performance and mechanisms to control agency problems between managers and shareholders. Journal of financial and quantitative analysis, 31(03), 377-397.

Almajali, Y. A., Alamro. A \& Al-Soub, Z. Y. (2012). Factors Affecting the Financial performance of Jordanian Insurance Companies Listed at Amman Stock Exchange. Journal of Management Research, 4(2), 226-289

Al-Tamimi, Yahia Z., et al. (2010). A review of delayed ischemic neurologic deficit following aneurysmal subarachnoid hemorrhage: historical overview, current treatment, and pathophysiology. World neurosurgery 73.6 (2010): 654-667.

Aburime, (2005) Determinants of Bank Profitability. Company-Level Evidence from Nigeria.

Anderson, M. \& Reeb (2004). Board characteristics, accounting report integrity, and the cost of debt. Journal of accounting and economics, 37(3), 315-342.

Anglo-Saxon, K. (1970). The O'Donnell lectures for 1967-8; delivered in the University of Oxford on 23 and 24 May 1968. Oxford University Press..

Attari, K. R. (2012). The Optimal Relationship of Cash Conversion Cycle with Firm Size and Profitability. International Journal of Academic Research in Business and Social Sciences, 2(12), 189-203.

Cadbury, A. (1992) Report on the Committee on the Financial Aspects of Corporate Governance, Gee, London.

Chandra, (2001). Liquidity Management and Control: A Comparative Study of Torrent Pharma and Cipla

Chaudey M. \&Fadairo M. (2010). Contractual design and networks performance: empirical evidence from franchising, Applied Economics, 42(1), 529-533.

Chiarella, C., Pham, T., Sim, A.B., \& Tam, M. (1991). Determinants of Corporate Capital Structure: Australian Evidence. Sydney, Australia; Australian Research Council.

Chowdhury, A., Chowdhury, S.P. (2010). Impact of capital structure on firm's value: Evidence from Bangladesh, Business and Economic Horizons, 3(3)111-122.

Christopher, D. I. David, F. Larcker \& Madhav V. R.T. (n.a). The Accounting Review. 2. 231-255

Claessens, S. \& Fan, J. P. H.(2002). Corporate Governance in Asia: A Survey. International review of Finance, 3, 71-103.

Crabtree \& DeBusk, (2008). The effects of adopting the Balanced Scorecard on shareholder returns $24,8-15$

Demsetz, H. \& Lehn, K. (1985). The Structure of Corporate Ownership: Causes and Consequences. Journal of Political Economy, 93,1155-1177

Eljelly. (2004). Liquidity-Profitability Tradeoff: An empirical Investigation in an Emerging Market. International Journal of Commerce \& Management, 14 (2), 48 -61 . 
Graham, J. R., \& Harvey, C.R. (2001). The theory and practice of corporate finance: Evidence from the field. Journal of Financial Economics, 60(2-3), 187-243.

Hovakimian, A.G, \& Tehranian, H. (2002). Determinants of Target Capital Structure: The Case of Combined Debt and Egypt Financing. Seminar presentation at Baruch College, New York. 